\title{
Caracterización de fibras en forma de lana de roca para aislamiento obtenidas a partir de basaltos canarios
}

\section{Characterization of fibers as rockwool for insulation obtained from canary islands basalts}

J.M. CÁCERES, J.E. GARCÍA HERNÁNDEZ; Dpto. de Edafología y Geología, Univ. La Laguna, Tenerife J.M RINCÓN; Lab. Materiales Vitrocerámicos (IETCC-CSIC)

Fecha de recepción. 21-III-96

Fecha de aceptación: 30 -V-96

ESPAÑA

\begin{abstract}
RESUMEN
Se ha obtenido fibra de vidrio en forma de lana, a escala de laboratorio, a partir de tres muestras de rocas basálticas de la Isla de Tenerife. La lana de roca se emplea extensamente como aislamiento térmico y acústico. La aptitud de estas rocas para su fibrado, estudiada mediante las curvas de viscosidad, mejora considerablemente con la adición de calcio y magnesio. Las fibras experimentales, obtenidas tanto a partir de las rocas directamente, como mezcladas en diferentes proporciones con $\mathrm{CaCO}_{3}$ o $\mathrm{CaMg}\left(\mathrm{CO}_{3}\right)_{2}$, se han caracterizado en lo referente a la composición química, la microestructura y propiedades térmicas y mecánicas. Asi mismo, se han comparado estas propiedades con las determinadas para cuatro muestras comerciales de lana de roca, permitiendo comprobar que son bastante semejantes, lo que hace prever unas buenas cualidades para estas fibras de basaltos canarios en aplicaciones de aislamiento térmico y acústico.
\end{abstract}

\section{SUMMARY}

Glass fibers in the shape of wool were obtained at laboratory scale from three samples of basaltic rocks from the Tenerife Island. The rockwool is widely used as thermal and acoustical insulation. The ability of these rocks to be fiberized was studied by means of the viscosity curves and can be quite improved by adding calciumand magnesium. The experimental fibers obtained from the rocks directly or mixed with either $\mathrm{CaCO}_{3}$ or $\mathrm{CaMg}\left(\mathrm{CO}_{3}\right)_{2}$ were characterized in terms of chemical composition, microstructure and thermal and mechanical properties. These properties were compared with the ones determined for four commercial samples of rockwool, founding that they are very close. This gives good prospects to these fibers from Canarian basalts as insulation material.

\section{INTRODUCCIÓN}

En la terminología de las fibras de vidrio, se denomina "lana" a un entramado de fibras cortas (longitud del orden de $\mathrm{cm}$ ) sin orden aparente alguno, en contraste con el filamento continuo o vidrio textil. El término "lana mineral" hace referencia a las materias primas de partida, que pueden ser rocas, escorias o composiciones sintéticas análogas a las de los vidrios convencionales,

\section{INTRODUCTION}

In the fiber glass terminology, "wool" is referred to a cloud of short fibers (length in the order of $\mathrm{cm}$ ) without any given order, contrasting with the continuous filament or textile glass. The term "mineral wool" refers to the raw materials that can be rocks, slags or synthetic compositions similar to the bulk regular glasses. The last ones are usually 
si bien estas ultimas se suelen referir exclusivamente como lana de vidrio (1).

Los numerosos poros ocluídos en este entramado de fibras le confieren a la lana mineral una conductividad térmica singularmente baja, así como un elevado coeficiente de absorción sonora, cualidades que han posibilitado su uso extendido como aislamiento térmico y acústico. A su vez, poseen otras valiosas propiedades como: incombustibilidad, notable inercia química y no favorecer el crecimiento ni el desarrollo de microorganismos, que se convierten en sus principales ventajas frente a otros materiales aislantes como, por ejemplo, los plásticos porosos (espumas).

La lista de materias primas empleadas en la obtención de lana de rocas y escorias es considerablemente extensa: granito, calcita, pizarra, basalto, diabasa, gabro, etc., entre las rocas, y escorias de hierro y acero procedentes de altos hornos, entre el segundo grupo formado por residuos industriales, además de escorias de otros metales como cromo, plomo o cobre. Las rocas de tipo basáltico presentan una serie de ventajas por sí mismas: composición química y mineralógica relativamente homogénea, gran abundancia y óptima temperatura de fusión (en torno a $1.100-1.300^{\circ} \mathrm{C}$ ), todo la cual las hace, a priori, muy aptas para el procesado a escala industrial. La investigación desarrollada acerca del uso de basaltos para la producción de fibra es amplia, y actualmente son numerosas las plantas industriales de producción de lana de roca a partir de basalto, repartidas por todo el mundo. Cabe destacar los trabajos de Wojnárovits y col. (2-3) relativos a las propiedades térmicas y químicas de la lana de basalto, enfocados a su uso como aislante térmico-acústico y como refuerzo de cementos. Este último aspecto revierte una especial importancia pues supone una aplicación con numerosas posibilidades, adicional a la del aislamiento en sí.

Ramachandran y col. (4), destacan la excelente resistencia de las fibras continuas de basalto al medio fuertemente alcalino, aspecto de vital importancia debido al elevado $\mathrm{pH}$ del cemento tipo Portland durante su hidratación (cercano a 13) (5). Otros autores, como Subramanian y col., destacan las aptitudes de estas fibras en la fabricación de composites con diferentes matrices como polímeros y madera (6-8).

En España, las rocas basálticas se localizan en Cataluña (en la comarca de Olot, Gerona ) y, de forma masiva, en las Islas Canarias. Vicente-Mingarro y col. (9) y Cáceres y col. (10) han realizado estudios preliminares sobre la obtención de fibras a partir de estos basaltos. El presente trabajo se plantea con el ánimo de investigar la aplicación de nuevas vías de procesado para la obtención de productos de interés named exclusively as glaswool (1).

The numerous pores occluded in this cloud of fibers give a really low thermal conductivity to the mineral wool, and a high acoustic absorption coefficient, allowing its extended use as thermal and acoustic insulation. At the same time, they have other valuables properties like: fireproof, high chemical durability and the capability to prevent the growing up of germs, becoming the main advantages over other insulation materials like the porous plastics (foams).

The relation of raw materials used in the manufacture of rock-and slag-wool is specially long: granite, diabase, lime, slate, basalt, gabbro, etc. between the rocks; steel and iron slag from blast furnaces in the second group, as well as non-ferrous metals slag like chromiun, lead and copper. The basaltic rocks possess several advantages by their own: a relatively homogenous chemical and mineralogical composition, a large abundance and an optimum melting temperature (about $1.100-1.300^{\circ} \mathrm{C}$ ). Thus they are a priori very suitable for an industrial process. The research developed about the use of basalts in the production of fibers is extensive, and nowadays the industrial plants producing rockwool from basalts are numerous around the world. Wojnarovits et al. (2-3) studied the thermal and chemical properties of the basaltwool, applied like thermo-acoustic insulation and cement reinforcement. The last aspect involves a special importance because it is an application with many possibilities, in addition to the insulation.

Ramachandran et al. (4) point out the excellent resistance of the basalt fibers to the alkaline attack, a key fact because the very high $\mathrm{pH}$ of the Portland type cement during its hydratation (5). Other authors, like Subramanian et al. (6-8), highlight the aptitudes of these fibers in making composites with different matrices like polymers and wood.

In Spain the basaltic rocks are located in Cataluña (Olot region) and massively in the Canary Islands. Vicente-Mingarro et al. (9) and Cáceres et al. (10) have done preliminary studies about the fiber obtention from those basalts. This paper is proposed with the aim of researching new processing ways in order to get products with industrial interest (specifically mineral wool), starting from the natural raw materials present 
industrial, concretamente lana mineral, a partir de las materias primas naturales presentes en Canarias. Con ese objetivo se ha obtenido fibra de vidrio en forma de lana de roca, a escala de laboratorio, a partir de tres muestras de rocas basálticas de la Isla de Tenerife, y se ha caracterizado en lo referente a la composición química, la microestructura y las propiedades térmicas y mecánicas. Asimismo, se han comparado estas propiedades con las determinadas para cuatro muestras de tipo comercial de lana de roca.

\section{EXPERIMENTAL}

Las rocas de partida son dos basaltos olivínicoaugíticos, denominados B1 y B5, y un traquibasalto, B2, cuyas localizaciones en el mapa de la Isla de Tenerife se representan en la Figura 1. Para su selección se tuvo en cuenta que no se encontrasen in the Canary Islands. With this objective, glass fiber was obtained in the shape of rockwool, at laboratory. scale, from three samples of basaltic rocks from Tenerife Island. The chemical composition, the microstructure and the thermal and mechanical properties were characterized. In addition, these properties were compared with the ones determined for four commercial samples of rockwool.

\section{EXPERIMENTAL}

The original rocks are two olivinic-augitic basalts, named BI and B5, and a trachybasalt, B2, which locations on the Tenerife Island map are plotted in Figure 1. For their selection it was taken into account that the samples were not located in zones used for

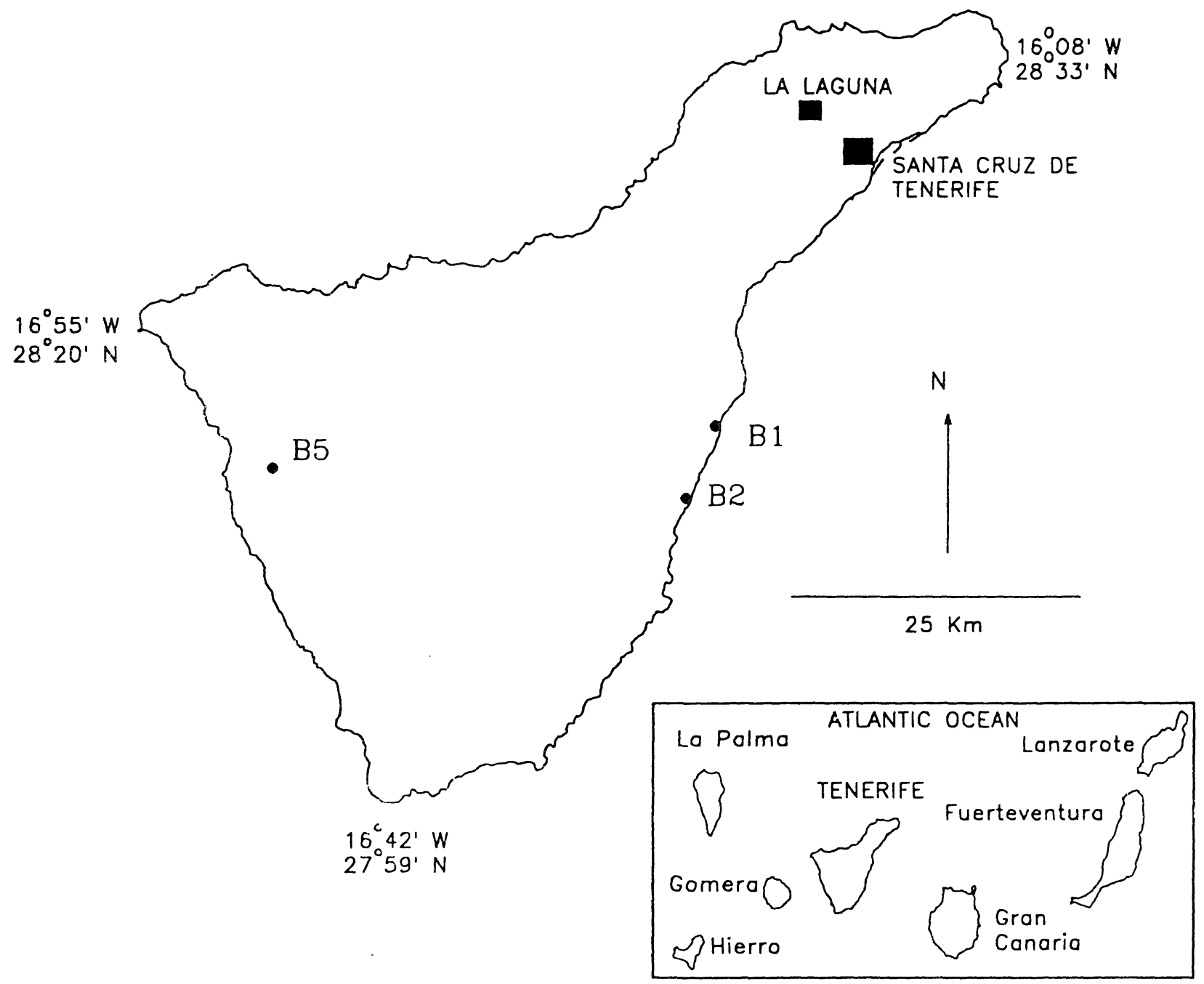

Fig. 1.- Localización de las muestras en el mapa de la Isla de Tenerife.

Fig. 1.- Samples location on the Tenerife Island map. 
localizadas en zonas dedicadas a actividades (agraria, urbanística) que impidiesen su extracción masiva, y que a su vez estos enclaves fuesen lo suficientemente accesibles. La composición química de las tres muestras se recoge en la Tabla I, y su representación en un diagrama TAS (sílice frente a suma de álcalis) en la Figura 2. Los basaltos B1 y B5 tienen una composición similar, situándose ambos en la zona tefrita-basanita, mientras que B2 se sitúa en la zona correspondiente a traquiandesita, con mayor contenido en sílice.

Las curvas de viscosidad-temperatura se estimaron a partir de la composición química, usando el modelo propuesto por Lakatos y col. (11) para silicatos fundidos formadores de lana mineral. Según este modelo, la temperatura (en ${ }^{\circ} \mathrm{C}$ ) correspondiente a una $\operatorname{viscosidad}(\eta)$ se puede calcular por medio de la expresión:

$\mathrm{T}_{\eta}=\mathrm{Ax} \frac{\mathrm{b}_{0}-\mathrm{SiO}_{2}-\mathrm{b}_{1} \mathrm{xAl}_{2} \mathrm{O}_{3}}{\mathbf{b}_{2} \mathrm{xCaO}+\mathrm{b}_{3} \times \mathrm{MgO}+\mathbf{b}_{4} \times \mathrm{Alk}+\mathrm{b}_{5} \times \mathrm{FeO}+\mathrm{b}_{6} \times \mathrm{Fe}_{2} \mathrm{O}_{3}}[1]$

con los componentes expresados en $\%$ en peso y los valores de los coeficientes $A$ y $b_{i}$ tabulados por dichos autores para tres valores de viscosidad: $\log \eta=1,5,2,0$ y 2,5 ( $\eta$ en dPas, $1 \mathrm{dPas}=1$ Poise). other activities (agriculture, urbanization) which could prevent their massive extraction. At the same time these enclaves should be accessible. The chemical composition of the three samples is shown on Table I and the representation in a TAS (total alkalis vs silica) on Figure 2. The basalts BI and B5 have a close composition, both in the tephrite-basanite zone, while sample B2 is in the trachyandesite zone, with a higher content in silica.

The viscosity vs temperature curves were estimated from the chemical composition, applying the model proposed by Lakatos et al. (11) for molten silicates formers of mineral wool. For this model, the temperature (in ${ }^{\circ} \mathrm{C}$ ) corresponding to a viscosity $(\eta$ ) is calculated by the expresion:

$T_{\eta}=A x \frac{b_{o}-S_{i O} O_{2}-b_{1} x \mathrm{Al}_{2} \mathrm{O}_{3}}{b_{2} x \mathrm{CaO}+b_{3} x \mathrm{MgO}+b_{4} x \mathrm{Alk}+b_{5} x \mathrm{FeO}+b_{6} x \mathrm{Fe}_{2} \mathrm{O}_{3}}[I J$

with the components in weight \% and the coefficients $A$ and $b_{i}$ tabulated by the authors for three viscosity values: $\log \eta=1.5,2.0$ y 2.5 ( $\eta$ in dPas, IdPas $=1$ Poise).

TABLA I (TABLE I)

Composición química de las muestras originales de rocas (en \% en peso) (Chemical composition of the original rock samples (in weight \%))

\begin{tabular}{|c|r|r|r||}
\hline $\begin{array}{c}\text { Muestra } \\
\text { (Samp/e) }\end{array}$ & $\mathrm{B} 1$ & $\mathrm{~B} 2$ & $\mathrm{~B} 5$ \\
\hline $\mathrm{SiO}_{2}$ & 43,20 & 50,00 & 44,20 \\
$\mathrm{Al}_{2} \mathrm{O}_{3}$ & 15,60 & 18,40 & 16,70 \\
$\mathrm{Fe}_{2} \mathrm{O}_{3}$ & 3,17 & 2,69 & 3,16 \\
$\mathrm{FeO}$ & 7,96 & 4,92 & 8,77 \\
$\mathrm{MnO}$ & 0,18 & 0,20 & 0,17 \\
$\mathrm{MgO}$ & 5,32 & 2,96 & 4,91 \\
$\mathrm{CaO}$ & 11,50 & 8,38 & 10,30 \\
$\mathrm{Na}_{2} \mathrm{O}$ & 4,85 & 5,22 & 4,82 \\
$\mathrm{~K}_{2} \mathrm{O}$ & 0,85 & 1,74 & 1,33 \\
$\mathrm{P}_{2} \mathrm{O}_{5}$ & 1,13 & 1,24 & 0,98 \\
$\mathrm{TiO}_{2}$ & 4,09 & 2,73 & 3,60 \\
$\mathrm{SO}_{3}$ & 0,04 & 0,03 & 0,02 \\
$\mathrm{LOI}$ & 1,80 & 1,18 & 0,41 \\
\hline $\mathrm{TOTAL}^{2}$ & 99,69 & 99,69 & 99,37 \\
\hline
\end{tabular}




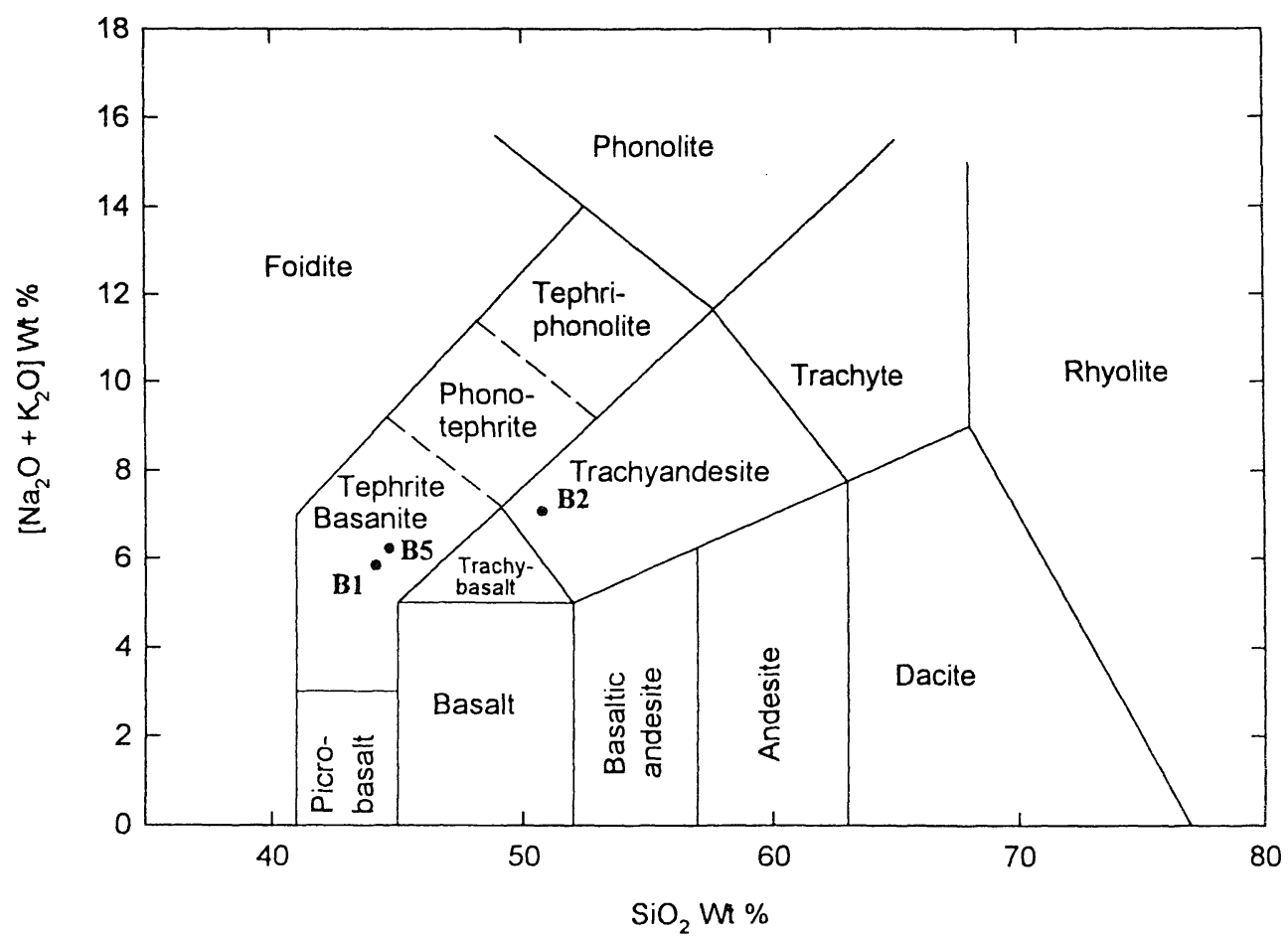

Fig. 2.- Clasificación TAS (sílice frente a suma de álcalis) de las rocas muestreadas.

Fig. 2.- TAS classification (total alkalis vs silica) of the rock samples.

Para la obtención de las fibras se empleó un dispositivo diseñado y construido en nuestros laboratorios, expresamente para este fin. Basado en el proceso J.M., de uso extendido en la industria de lana de rocas y escorias (12), permite transformar al material fundido en fibras en forma de lana, por dispersión al colarlo entre dos rodillos de grafito girando en sentidos opuestos a $10.000 \mathrm{rpm}$. En todos los casos el material de partida se fundió en un horno eléctrico a $1.400{ }^{\circ} \mathrm{C}$ durante $30 \mathrm{~min}$, en atmósfera de aire, usando crisoles de material silicoaluminoso suministrados por la firma Lomba Camiña (Pontevedra, España).

La fibra se obtuvo a partir de las tres muestras antes reseñadas (B1, B2 y B5), ya sea directamente (sin ningún tipo de aditivo) o bien mezcladas con distintas proporciones de $\mathrm{CaCO}_{3}$ o $\mathrm{CaMg}\left(\mathrm{CO}_{3}\right)_{2}$. Las ocho composiciones estudiadas en el presente trabajo se indican en la Tabla II, junto a la nomenclatura empleada. Con el objeto de comparar las fibras obtenidas experimentalmente con las producidas a escala industrial, se tomaron cuatro muestras de lana de roca comercial, cuya identificación se indica en la Tabla III.

La composición química de las fibras (elementos mayoritarios) se determinó siguiendo el método de Bea Barredo y Polo Díez (13), llevando las muestras a disolución mediante fusión alcalina y posterior digestión ácida. Tanto para las fibras experimentales
A device designed and built just with this purpose in our laboratories was used to obtain the fibers. It is based in the .JM process, common in the rock-and slag-wool industry (12), and transforms the molten batch in fibers in the shape of wool by dispersing the cast between two graphite wheels spinning at 10.000 rpm in opposite directions. In all the cases the starting batch was melted in an electrical furnace at $1.400^{\circ} \mathrm{C}$ during $30 \mathrm{~min}$, in air, using silica-alumina crucibles supplied by the company Lomba CamiZa (Pontevedra, Spain).

The fiber was made from the three noted samples (B1. B2 and B5) directly (without any additives) or by mixing with different propotions either $\mathrm{CaC} \mathrm{O}_{3}$ or $\mathrm{CaMg}\left(\mathrm{CO}_{3}\right)_{2}$. The eight compositions studied in the present paper are shown in Table II with the nomenclature used. Four samples of commercial rockwool were chosen for comparing the experimental made fibers with the ones produced at industrial scale (Table III).

The chemical composition of the fibers (major elements) was determined following the method of Bea Barredo and Polo IDRez (13), putting the samples into dissolution by means of alkaline melting and subsequent acid digestion. The measures were done in 
Composición y nomenclatura usada para las fibras experimentales (Composition and nomenclature used for the experimental fibers)

\begin{tabular}{|c|c|}
\hline $\begin{array}{c}\text { Muestra } \\
\text { (Sample) }\end{array}$ & $\begin{array}{c}\text { Composición* } \\
\text { (Composition) }\end{array}$ \\
\hline 1 & $\mathrm{~B} 1$ sin aditivos (Without aditives) \\
\hline $1 \mathrm{C} 15$ & $\mathrm{~B} 1+15 \% \mathrm{CaCO}_{3}$ \\
\hline $1 \mathrm{D} 15$ & $\left.\mathrm{~B} 1+15 \% \mathrm{CaMg}^{*} \mathrm{CO}_{3}\right)_{2}$ \\
\hline $2 \mathrm{C} 20$ & $\mathrm{~B} 2+20 \% \mathrm{CaCO}_{3}$ \\
\hline 5 & $\mathrm{~B} 2+20 \% \mathrm{CaMg}_{\left(\mathrm{CO}_{3}\right)_{2}}$ \\
\hline $5 \mathrm{C} 15$ & $\mathrm{~B} 5 \sin$ aditivos $($ without aditives) \\
\hline $5 \mathrm{D} 15$ & $\mathrm{~B} 5+15 \% \mathrm{CaCO}_{3}$ \\
\hline
\end{tabular}

* Las proporciones son el \% en peso en la mezcla (por ejemplo, $1 \mathrm{C} 15$ significa $85 \%$ de $\mathrm{B} 1+15 \%$ de $\mathrm{CaCO}_{3}$ )

* (The proportions are in weight \% in the mixture (for example $1 \mathrm{C} 15$ means $85 \%$ of $\mathrm{B} 1+15 \%$ of $\mathrm{CaCO}_{3}$ ))

TABLA III (TABLE III)

Muestras de lana de roca comercial

(Samples of commercial rockwool)

\begin{tabular}{||c|c|c||}
\hline $\begin{array}{c}\text { Nombre } \\
\text { (Name) }\end{array}$ & $\begin{array}{c}\text { País de origen } \\
\text { (Country of origin) }\end{array}$ & $\begin{array}{c}\text { Aplicación } \\
\text { (Application) }\end{array}$ \\
\hline Rockwool & Alemania (Germany) & Aislamiento (Insulation) \\
Eurocoustic & Francia (France) & Aislamiento (Insulation) \\
Izolacja & Polonia (Poland) & Aislamiento (Insulation) \\
Cultilene & Dinamarca (Denmark) & Suelo artificial (Artificial soil) \\
\hline
\end{tabular}

como comerciales las medidas se realizaron en un espectrofotómetro de absorción atómica Perkin-Elmer 3100. El estudio por Microscopía Electrónica de Barrido (MEB) se efectuó en un microscopio Hitachi S450 y en un Zeiss DSM-950, previo recubrimiento de las muestras con una capa de oro. Las fibras experimentales se caracterizaron, asimismo, por Microscopía Electrónica de Transmisión (MET) en un equipo Siemens, empleando la técnica de réplica directa de carbón sobre superficies recientes de fractura en las fibras, atacadas con $\mathrm{HF}$, al $2 \%$, durante $15 \mathrm{~s}$.

Los difractogramas de Rayos X se obtuvieron en un Philips PW-1720 usando radiación CoK $\alpha$ ", mediante el an Atomic Abortion Spectrophotometer Perkin-Elmer 3100. The Scanning Electron Microscopy (SEM) study was performed using a Hitachi S450 and a Zeiss DSM950, prior gold coating of the samples. The experimental fibers were also characterized by Transmission Electron Microscopy (TEM) in a Siemens equipment, using the direct carbon replica technique over recent fracture sections of the fibers, prior attack with $H F$ (2\%) during 15 s.

The X-Rays Diffraction (XRD) was performed in a Philips $P W-1720$ powder diffractometer with CoK $\alpha$ " 
método del polvo desorientado, y los diagramas de Análisis Térmico Diferencial (ATD) en un equipo Perkin-Elmer DTA 1700 , en atmósfera de aire, a una velocidad de calentamiento de $8{ }^{\circ} \mathrm{C} \mathrm{min}^{-1}$, entre temperatura ambiente y $1.100^{\circ} \mathrm{C}$, sobre las muestras previamente pulverizadas.

Para determinar la resistencia mecánica a la tracción se extrajeron de la lana filamentos de unos 8 a $10 \mathrm{~cm}$ de largo, que se dividieron en dos mitades. A partir de una se determinó el área de la sección de la fibra mediante un vibroscopio electromecánico, siguiendo el procedimiento descrito por la norma ASTM D1577-90 para fibras de tipo textil (14). Se presentan los resultados para dos composiciones, 5 y 5D15, pues del resto no fue posible extraer fibras lo suficientemente largas como para ser ensayadas. La densidad de las fibras es $2,12 \mathrm{gcm}^{-3}$ para la muestra 5 y $2,39 \mathrm{gcm}^{-3}$ para 5D15. La otra mitad de cada filamento se ensayó en una máquina de ensayos a tracción Instron 1122, a una velocidad de estiramiento de $0,2 \mathrm{~mm} \cdot \mathrm{min}^{-1}$ para un largo inicial de la fibra de $20 \mathrm{~mm}$. La tensión de rotura se calculó a partir de la carga de rotura y del área de la sección de la fibra, medida para el fragmento adyacente correspondiente. Un mínimo de 25 ejemplares se ensayó para cada caso.

\section{RESULTADOS Y DISCUSIÓN}

\subsection{Materias primas: curvas de viscosidad}

De los factores a estudiar en las materias primas, la viscosidad resulta esencial por ser determinante a la hora de transformar el material fundido en fibras. Esto es debido, principalmente, a que los procesos de formación de lana mineral consisten en la dispersión (por centrifugado, por medio de gas o vapor a presión, o por combinaciones de ambos) del material fundido en infinidad de pequeñas gotas que, por estiramiento, dan lugar a las fibras. Así, la viscosidad debe ser la adecuada para permitir la formación de fibras con un diámetro en torno a las $10 \mathrm{~m}$. Según Zhilin [citado en (15)] el rango óptimo de viscosidad para la formación de lana mineral es de 5 a 15 días entre 1.500 y $1.400^{\circ} \mathrm{C}$. Lakatos y col., por su parte, sugieren un valor de 30 días a una temperatura de $1.371{ }^{\circ} \mathrm{C}(11)$.

Utilizando el modelo propuesto por el propio Lakatos y col. (11) para calcular la temperatura a la que un material fundido (de similar composición a nuestras muestras basálticas) alcanzaría viscosidades de $\log \eta=2,5,2,0$ y 1,5 (en dPas), se obtuvieron los valores representados en la Figura 3. A partir de estos tres puntos se calcularon los coeficientes de la ecuación VFT (Vogel-FulcherTammann), que es la expresión más aceptada para representar el comportamiento de la viscosidad con la radiation, and the Differential Thermal Analysis (DTA) in a Perkin-Elmer DTA 1700 equipment, in air, with a heating a rate of $8^{\circ} \mathrm{C} \mathrm{min} \mathrm{m}^{-1}$ between room temperature and $1.100^{\circ} \mathrm{C}$.

The tensile strength was measured on removed filaments from the wool, with 8 to $10 \mathrm{~cm}$ length. The data are reported only for the 5 and 5D15 samples because for the other ones was not possible to remove fibers long enough. Each filament was divided in half. Using one half, the cross-sectional area of each fiber was determined by means of an electromechanical vibroscope, following the standard test method ASTM D1577-90 for textile fibers (14). The mass density is $2.12 \mathrm{gcm}^{-3}$ and $2.39 \mathrm{gcm}^{-3}$ for the 5 and $5 D 15$ samples respectively. The other half of the fiber was tested using an Instron 1122 tension testing machine at a strain rate of $0.2 \mathrm{~mm} \cdot \mathrm{min}^{-1}$ and at a gauge length of 20 $\mathrm{mm}$ for the fibers. The failure stress was calculated using the maximum load and the cross-sectional area measured on that particular fiber's adjacent half. $A$ minimum of 25 successful tests were performed for each case.

\section{RESULTS AND DISCUSSION}

\subsection{Raw materials: viscosity curves}

From the different factors to study in the raw materials, the viscosity becomes essential to transform the molten material into fibers. This is mainly because the mineral wool forming processes consist in the scattering of the molten material by spinning, blowing or combinations of both) in a infinite number of small drops that, by stretching, from the fibers. In this sense, the viscosity should be the suitable one that allows the fibers formation, with a diameter about $10 \mathrm{~m}$. According to Zhilin [cited in (15)] the optimum viscosity range for the mineral wool formation is 5 to 15 dPas between 1.500 and $1.400^{\circ} \mathrm{C}$. Lakatos et al. (11) suggest a value of $30 \mathrm{dPas}$ at $1.371^{\circ} \mathrm{C}$.

The values represented in Figure 3 were obtained using the model proposed by these authors for calculating the temperatures at what a molten material, with a similar composition to our basaltic samples, would reach viscosities of $\log \eta=2.5,2.0 y$ 1.5 ( $\eta$ in dPas). From these three points the coefficients of the VFT equation Vogel-FulcherTammann) were calculated. This relation is the most accepted one to describe the viscosity behavior with 

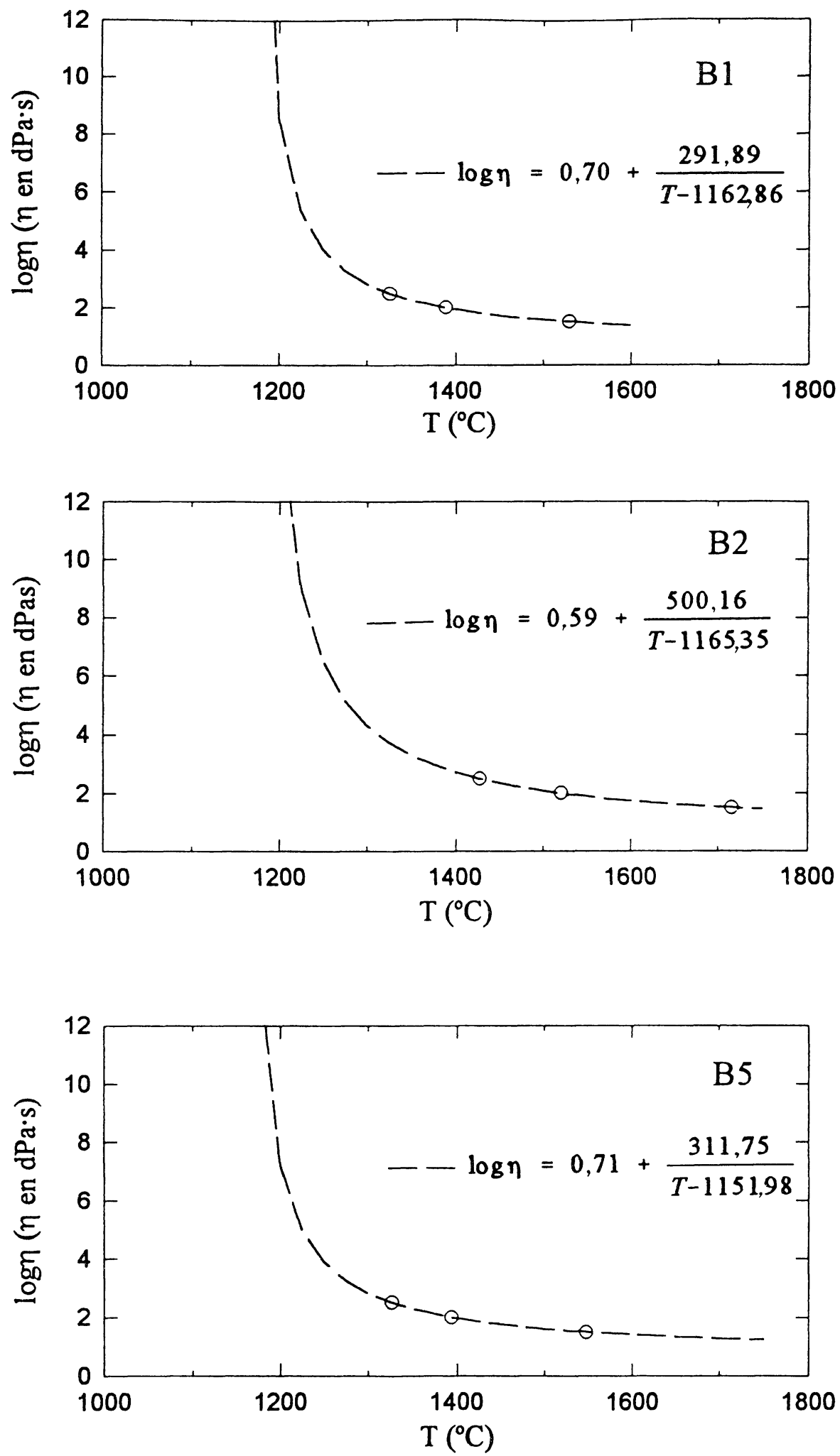

- Puntos calculados (calculated points)

- Curva VFT (VFT curve)

Fig. 3.- Gráficas $\log \eta$ frente a $T$ de los valores de viscosidad calculados a partir de la composición, y de las curvas VFT deducidas a partir de ellos, para las rocas originales.

Fig. 3.- Plots $\log \eta v s . T$ of the original rocks samples, for the viscosity values calculed from the composition, and for the VFT curves deduced from them. 
temperatura en un vidrio (16). Las curvas correspondientes se representan como líneas a trazos en la figura 3. Para las muestras B1 y B5 la temperatura correspondiente a una viscosidad de $\log \eta=1,5(=30$ $\mathrm{dPas}$ ) es de 1.530 y $1.545^{\circ} \mathrm{C}$ respectivamente, sensiblemente superiores a la considerada óptima por Lakatos: $1.371^{\circ} \mathrm{C}$. Para la muestra B2 esta temperatura se sitúa en $1.716^{\circ} \mathrm{C}$, en concordancia con su mayor contenido en $\mathrm{SiO}_{2}$ y $\mathrm{Al}_{2} \mathrm{O}_{3}$ respecto a las otras dos.

Todo ello conlleva a la necesidad de añadir óxidos de calcio y magnesio con el objeto de disminuir dicha temperatura, en mayor medida para la muestra B2. Aún así, a partir de los basaltos B1 y B5 es posible obtener fibra directamente, sin necesidad de aditivos, si bien la cantidad de fibra es escasa y, a primera vista, su diametro elevado. Estos factores se ven notablemente mejorados por la adición de $\mathrm{CaCO}_{3}$ y $\mathrm{CaMg}\left(\mathrm{CO}_{3}\right)_{2}$ en un $15 \%$ en peso. Para la muestra $\mathrm{B} 2$ es necesario añadir un $20 \%$ en peso de uno de estos carbonatos para obtener unas fibras aceptables; en caso contrario la viscosidad del material fundido no es lo suficientemente baja como para que se disperse y forme las fibras.

\subsection{Fibras experimentales}

La Tabla IV recoge el contenido en elementos mayoritarios determinado para las ocho composiciones de fibras obtenidas experimentalmente. No se observa una variación importante respecto a la composición de las rocas de partida (Tabla I), salvo un mayor contenido en $\mathrm{Al}_{2} \mathrm{O}_{3}$ para las muestras 1 y 5 , consecuencia de la difusión entre el material fundido y el crisol (de tipo sílico-aluminoso). the temperature for a glass (16). The corresponding curves are plotted with dashed lines in Figure 3. The temperature at a $\log \eta=1.5(\eta=30 \mathrm{dPas})$ viscosity for the samples BI and B5 is 1.530 and $1.545^{\circ} \mathrm{C}$ respectively, slightly above the assumed as optimum by Lakatos et al. For $B 2$ this temperature is $1.716^{\circ} \mathrm{C}$, in concordance with the higher content in $\mathrm{SiO}_{2}$ and $\mathrm{Al}_{2} \mathrm{O}_{3}$ regarding the other two.

This entails to the necessity of adding calcium and magnesium oxides with the purpose of reducing that temperature, mainly for B2 sample. However, it is possible to get fiber from the BI and B5 basalts, without additives, but the fiber quantity is low and, at first sight, the diameter large. This aspect are remarkablely improved adding $\mathrm{CaCO}_{3}$ or $\mathrm{CaMg}\left(\mathrm{CO}_{3}\right)_{2}$ in 15 weight \%. For the sample B2 it is needed to add up to 20 weight \% of one on these carbonates in order to obtain acceptable fibers. If not, the viscosity of the melt is not enough low to allow the cast scattering and the subsequent fiber formation.

\subsection{Experimental fibers}

The major elements contents determined for the eight compositions of experimentally obtained fibers is shown in Table IV. There is not too much change respect the original rocks (T'able I), unless a higher contents in $\mathrm{Al}_{2} \mathrm{O}_{3}$ for samples $\mathrm{I}$ and 5 , consequence of the diffusion between the melt and the crucible (of silica-alumina composition).

\section{TABLA IV (TABLE IV)}

Análisis químico de las fibras experimentales para algunos elementos mayores (en \% en peso) (Chemical analysis of the experimental fibers for some major elements (in weight \%)

\begin{tabular}{||c|c|c|c|c|c|c|c|c||}
\hline $\begin{array}{c}\text { Muestra } \\
\text { (Sample) }\end{array}$ & 1 & $1 \mathrm{C} 15$ & $1 \mathrm{D} 15$ & $2 \mathrm{C} 20$ & $2 \mathrm{D} 20$ & 5 & $5 \mathrm{C} 15$ & $5 \mathrm{D} 15$ \\
\hline $\mathrm{SiO}_{2}$ & 44,49 & 42,99 & 43,09 & 44,79 & 44,76 & 43,63 & 43,58 & 44,05 \\
\hline $\mathrm{Al}_{2} \mathrm{O}_{3}$ & 18,65 & 18,19 & 18,69 & 19,75 & 19,32 & 19,30 & 18,30 & 18,35 \\
\hline $\mathrm{Fe}_{2} \mathrm{O}_{3}{ }^{*}$ & 12,82 & 12,07 & 12,40 & 8,20 & 8,58 & 13,33 & 12,59 & 12,84 \\
\hline $\mathrm{MgO}$ & 6,91 & 5,99 & 8,86 & 3,26 & 7,72 & 7,63 & 5,69 & 8,44 \\
\hline $\mathrm{CaO}$ & 9,76 & 14,97 & 12,93 & 16,41 & 12,47 & 11,20 & 15,50 & 12,51 \\
\hline $\mathrm{Na} \mathrm{N}_{2} \mathrm{3}$ & 3,92 & 3,51 & 3,44 & 5,60 & 6,32 & 3,89 & 3,67 & 3,78 \\
\hline $\mathrm{K}_{2} \mathrm{O}$ & 0,99 & 0,93 & 0,87 & 1,50 & 1,46 & 1,45 & 1,28 & 1,29 \\
\hline
\end{tabular}

\footnotetext{
* Como hierro total: $\mathrm{FeO}+\mathrm{Fe}_{2} \mathrm{O}_{3}$ (as total iron: $\mathrm{FeO}+\mathrm{Fe}_{2} \mathrm{O}_{3}$ )
} 
El estudio de las muestras por MEB permite apreciar una distribución de diámetros muy amplia, entre $10 \mathrm{y}$ $50 \mu \mathrm{m}$ para las fibras de los basaltos B1 y B5 sin aditivos y para las dos composiciones derivadas del traquibasalto B2 (muestras 1, 5, 2C20 y 2D20), y sensiblemente menor, entre 5 y $30 \mu \mathrm{m}$, para las composiciones derivadas de los basaltos $\mathrm{B} 1$ y $\mathrm{B} 5$ con $\mathrm{CaCO}_{3}$ o $\mathrm{CaMg}\left(\mathrm{CO}_{3}\right)_{2}$ (muestras $1 \mathrm{C} 15,1 \mathrm{D} 15,5 \mathrm{C} 15$ y 5D15). En la Figura 4 se puede apreciar esta disminución en el rango de diámetros por efecto del carbonato, para el caso de las muestras 1 y $1 \mathrm{C} 15$. Por el propio método de obtención de las fibras, los filamentos que dejan tras de sí las gotas del material funcido al estirarse tienen un diámetro que disminuye de la cabeza a la cola, además de variar de una gota a otra. En cuanto al aspecto geométrico, éste es bastante homogéneo para las fibras obtenidas a partir de los basaltos $\mathrm{B} 1$ y $\mathrm{B} 5$ más $\mathrm{CaCO}_{3}$ o $\mathrm{CaMg}\left(\mathrm{CO}_{3}\right)_{2}$, en contraste con las otras cuatro muestras $(1,5,2 \mathrm{C} 20 \mathrm{y}$ 2D20), que presentan más irregularidades.
The study by SEM gives a broad diameter distribution, between 10 and $50 \mathrm{~m}$ for the fibers of the basalts $B I$ and B5 without additives and for the two compositions derived from the trachybasalt B2 (samples 1, 5, 2C20 and 2D20). It is slightly less, between 5 and $30 \mathrm{~m}$, for the compositions derived from $\mathrm{Bl}$ and $\mathrm{BS}$ with $\mathrm{CaCO}_{3}$ or $\mathrm{CaMg}\left(\mathrm{CO}_{3}\right)_{2}$ (samples $1 \mathrm{C15}, 1 \mathrm{D15}, 5 \mathrm{Cl} 15$ and 5D15). It is appreciable in Figure 4 this decrease in the diameters range as consequence of the carbonate for the samples 1 and 1C15. The method of manufacture implies by itself the decrease in the diameter of the filaments formed as the melt drops are stretched. This explains the broad diameter distributions obtained. The geometrical shape is very homogenous for the fibers obtained from $B 1$ and $B 5$ with $\mathrm{CaCO}_{3}$ or $\mathrm{CaMg}\left(\mathrm{CO}_{3}\right)_{2}$, in contrast with the other four samples $(1,5,2 C 20$ and 2D20), with more irregularities.
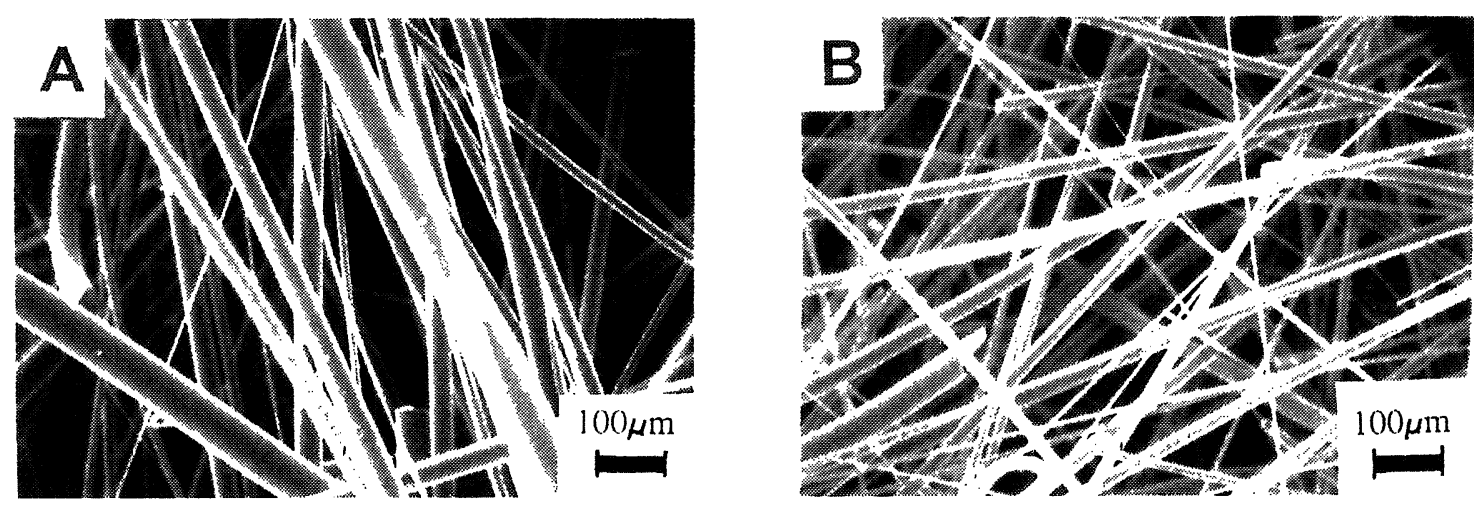

Fig. 4.- Micrografias MEB de las fibras experimentales: (A) muestra 1 y (B) muestra $1 \mathrm{C} 15$.

Fig. 4.- SEM micrographs of the experimental fibers.

Las fibras 1 y 5 se analizaron también por MET. Se corresponden con vidrios muy heterogéneos en ambos casos, tal como se puede apreciar en la Figura 5, con una alta separación de fases además de cristales redondeados, o gérmenes de ellos, que en algunos casos se observan agrupados en racimos. En la fibra 1 se observan cristalizaciones en el borde de la fibra de formas romboidales (Foto B), atribuibles a magnetita $u$ olivino, formados por desvitrificación o que no han llegado a fundir completamente. En el caso de la fibra 5 , las cristalizaciones aparecen en el interior y son de gran tamaño (Foto D). Por su hábito tabular y la composición química del material, cabe pensar que se trate de olivinos o plagioclasas.
Likewise, the fibers 1 and 5 were analyzed by TEM. They corresponds to very heterogenous glasses with high phase separation as well as round shape crystals or crystals seeds, which are linked in clusters in some cases (see Figure 5). In fiber 1 there are also crystallizations in the fiber edge with a rhombus shape (Photo B), probably magnetite or olivine formed by crystallization or because they were not completely melted. In the case of fiber 5 the crystals appear in the bulk and have a large size (Photo D). Should be olivines or plagioclases because the tabular form and the chemical composition of the fiber. 

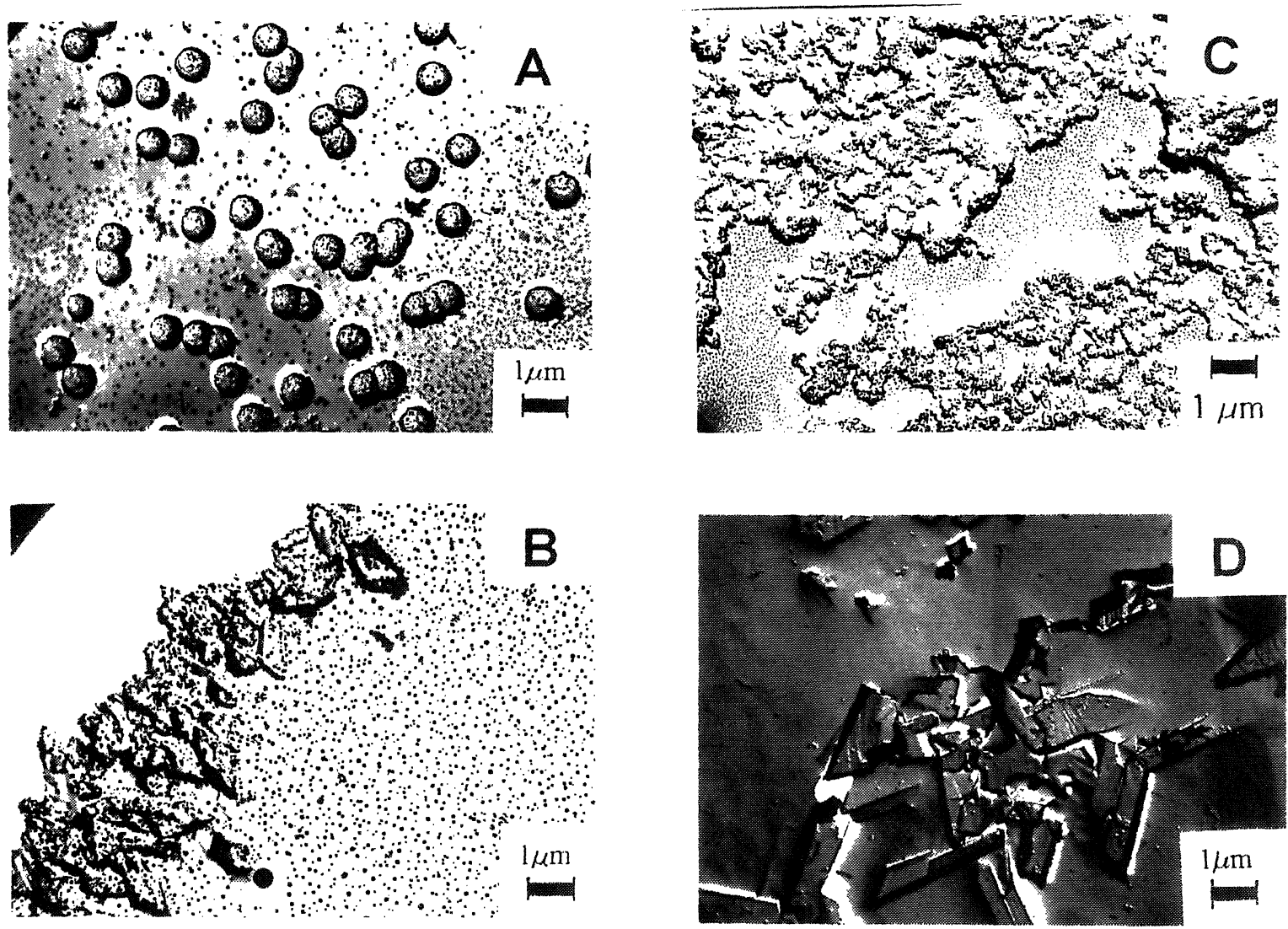

Fig. 5.- Micrografias MET de las fibras experimentales: (A) y (B) muestra 1; (C) y (D) muestra 5

Fig. 5.- TEM micrographs of the experimental fibers.

Las ocho composiciones de fibras estudiadas presentan hábitos típicos de vidrios amorfos por DRX. Los difractogramas (Figura 6) no presentan ninguna reflexión correspondiente a estructuras cristalinas, aunque sí un fondo bastante pronunciado, característico de los vidrios con alta tendencia a la cristalización. La curvas ATD (Figura 7) de las fibras experimentales presentan un sólo efecto exotérmico en la región de temperaturas estudiada (de ambiente a $1.100^{\circ} \mathrm{C}$ ), asociado a la cristalización de fases en el vidrio. Para las muestras derivadas del basalto B1 y del basalto B5 la temperatura de pico decrece, en ambos casos, desde $846{ }^{\circ} \mathrm{C}$ para las muestras sin aditivos (muestras 1 y 5 ), hasta $8411^{\circ} \mathrm{C}$ al añadir $\mathrm{CaCO}_{3}$ en un $15 \%(1 \mathrm{C} 15 \mathrm{y}$ $5 \mathrm{C} 15)$ y hasta $830^{\circ} \mathrm{C}$ si el aditivo es $\mathrm{CaMg}\left(\mathrm{CO}_{3}\right)_{2}$ (1D15 y 5D15). Así pues, cabe esperar que las fibras que contienen estos aditivos desvitrifiquen a menor temperatura que las que carecen de ellos. Para las derivadas del traquibasalto $\mathrm{B} 2$ la adición de $\mathrm{CaMg}\left(\mathrm{CO}_{3}\right)_{2}$ produce el efecto contrario, al elevar ligeramente la temperatura de pico, de 848 a $852^{\circ} \mathrm{C}$. En general, el $\mathrm{CaMg}\left(\mathrm{CO}_{3}\right)_{2}$ provoca, en todos los casos, efectos exotérmicos más intensos, lo que hace pensar que este compuesto favorece la desvitrificación de las fibras.
The eight studied compositions have a glassy behavior in DRX. The patterns do not show any reflection due to crystalline structures, but the baseline is high, typical of glasses with large tendency to crystallize (see Figure 6). The DTA curves for the experimental fibers have only one exothermic effect in the temperature range analyzed (room temperature to $1.100^{\circ} \mathrm{C}$ ), associated with the crystallization of phases in the glass (see Iigure 7). For the samples derived from the basalts BI and $B 5$ the peak temperature decreases, in both cases: from $846^{\circ} \mathrm{C}$ for the samples without additives ( $I$ and 5) to $841^{\circ} \mathrm{C}$ when $\mathrm{CaCO}_{3}$ is added in 15 weight \% $1(1 \mathrm{C} 15$ and $5 \mathrm{C} .15)$ and to $830^{\circ} \mathrm{C}$ if the additive is $\mathrm{CaMg}\left(\mathrm{C}^{\circ} \mathrm{O}_{3}\right)_{2}$ (1D15 and 5D15). In this sense, a lower desvitrification temperature for the fibers with additives that for the ones without them is expected. In the case of the fiher derived from the trachybasalt 132 the effect of adding $\mathrm{CaMg}\left(\mathrm{C}^{\prime} \mathrm{O}_{3}\right)_{2}$ is the opposite, increasing slightly the peak temperature from 848 to $852^{\circ} \mathrm{C}$ '. (ienerally the exothermic effects are more intense in the samples with $\mathrm{CaMg}\left(\mathrm{CO}_{3}\right)_{2}$, thus this compound favors the fiber desvitrification. 
Respecto a las propiedades mecánicas, la resistencia a la tracción determinada para las fibras 5 y $5 \mathrm{D} 15$ es de 639 y $717 \mathrm{MPa}$, con Módulos de Young de 89 y 86 $\mathrm{GPa}$, respectivamente. Así pues, el $\mathrm{CaMg}\left(\mathrm{CO}_{3}\right)_{2}$ tiene como efecto incrementar ligeramente la resistencia de las fibras. Los módulos están en consonancia con los reseñados por otros autores, que lo sitúan entre 80 y 90 $\mathrm{GPa}$, mientras que la resistencia a la tracción es considerablemente más baja, pues los valores encontrados en la literatura varían entre 1.500 y 2.000 $\operatorname{MPa}(4,6-8)$. Sin embargo, hay que tener en cuenta que se refieren a filamento continuo y que la influencia del estado de la superficie de la fibra en la resistencia a la tracción es determinante, pues cualquier defecto
In respect to the mechanical properties, the measured tensile strength for the fibers 5 and $5 D 15$ is 639 and 717 , with a Young 's Modulus of 89 and $86 \mathrm{GPa}$, respectively. The $\mathrm{CaMg}\left(\mathrm{CO}_{3}\right)_{2}$ increase in some amount the fibers strength. The Modulus values are similar with the reported ones by other authors (80-90 GPa), while the tensile strength is notablely lower, as the values in the bibliography are roughly between 1.500 and $2.000 \mathrm{MPa}$ (4, 6-8). However, must be considered that those results are referred to continuous filaments, and that the surface condition of the fibers have a strong influence in their strength because any defect helps the failure under tensile stress. In our case the situation is in some sense the less favorable because

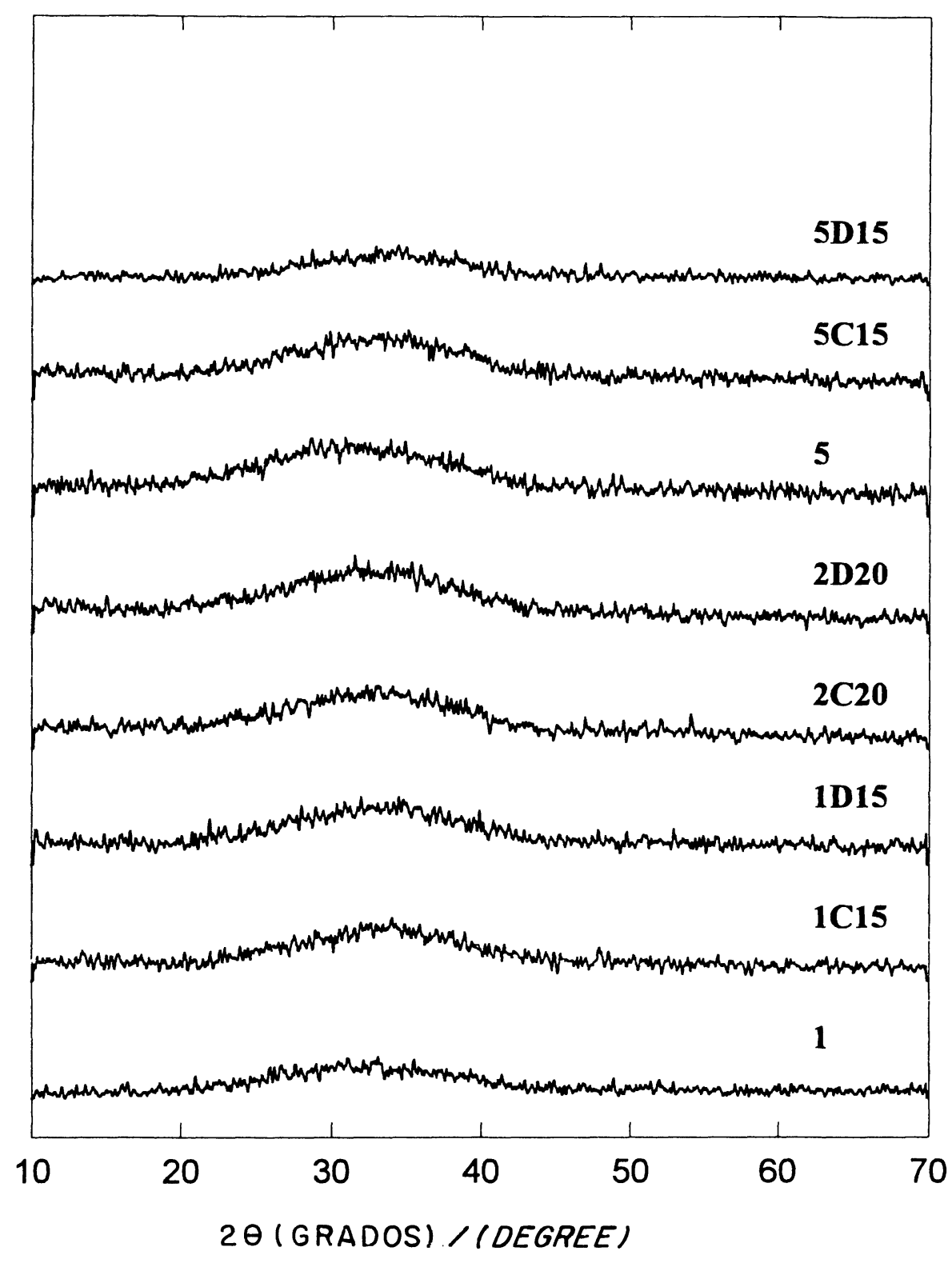

Fig. 6.- Difractogramas de rayos-X de las fibras experimentales. Rad. CoK $\alpha$.

Fig. 6.- XRD patterns for the experimental fibers. 

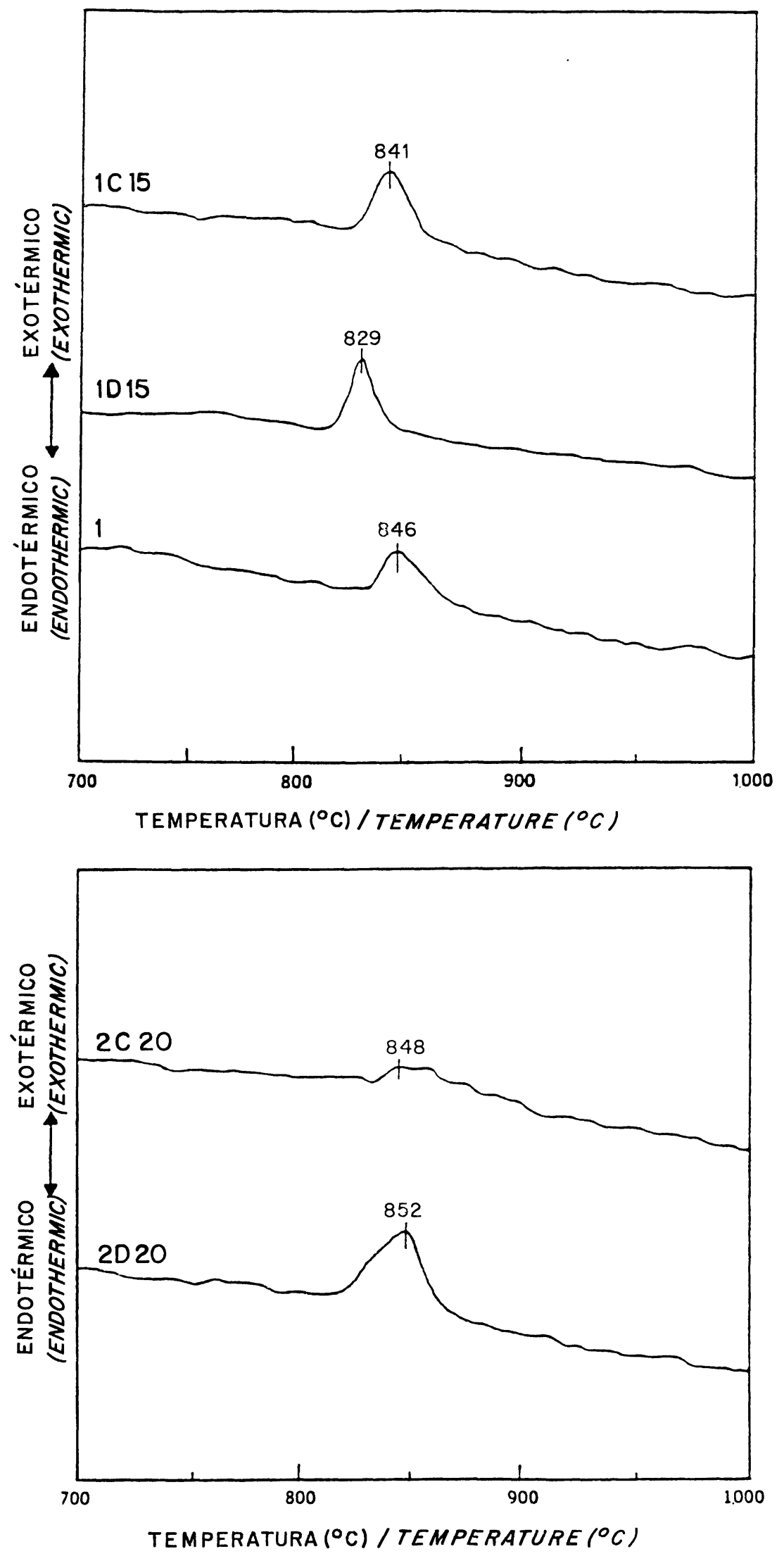

Fig. 7.- Curvas ATD de las fibras experimentales.

Fig. 7.- DTA curves for the experimental fibers. 
favorece su fractura. En nuestro caso la situación es, de alguna manera, la menos favorable, pues, por la propia naturaleza de la lana, existen fricciones entre las fibras que generan estos defectos. Es lógico esperar que la resistencia sea menor respecto al filamento continuo, menos expuesto a estas perturbaciones. Por otra parte, existe una dependencia de la resistencia a la tracción respecto al diámetro de las fibras, y así cuanto menor es el diámetro mayor es la resistencia, tal como indican Andreevskaya y col. (17), que recogen valores de 920 MPa para diámetros de $17 \mu \mathrm{m}$. Si tenemos en cuenta que nuestras fibras tienen diámetros medios entre 20-30 $\mu \mathrm{m}$, los valores de resistencia a la tracción encontrados no son muy dispares de los reseñados por dicho autor.

\subsection{Fibras comerciales}

Las composiciones de las muestras Rockwool y Eurocoustic (Tabla V) guardan gran paralelismo, lo que denota un origen similar. Izolacja destaca por su mayor contenido en hierro y magnesio, y menor en calcio. Cultilene es netamente diferente, con muy poco hierro y casi un $25 \%$ de $\mathrm{CaO}$; parece claro que su uso como suelo artificial condiciona la composición. there are frictions between the fibers in the wool, which generate those defects. Is expected then a lower strength respect the continuous filaments, not exposed to this damage. On the other hand, the tensile strength depends on the fiber diameter, thus lower the diameter higher is the strength, as Andreevskaya et al (17) mentions, who reports tensile strengths of $920 \mathrm{MPa}$ for a diameter of $17 \mu \mathrm{m}$. As the average diameter of our fibers is about 20-30 um, the determined tensile strength is not very far from those reported by Andresvskaya et al.

\subsection{Commercial fibers}

The compositions of the Rockwool and Eurocoustic samples (Table $V$ ) are very similar, showing a close origin. Izolacja has higher content in iron and magnesium and lower in calcium. Cultilene is quite different, with very low content in iron and near a $25 \%$ of $\mathrm{CaO}$; seems clear that the composition is conditioned by the use as artificial soil.

\section{TABLA $\vee(T A B L E V)$}

Análisis químico de las fibras comerciales (en \% en peso) (Chemical analysis of the commercial fibers (in weight \%))

\begin{tabular}{|c|c|c|c|c||}
\hline $\begin{array}{c}\text { Muestra } \\
\text { (Sample) }\end{array}$ & Rockwool & Eurocoustic & Izolacja & Cuitilene \\
\hline $\mathrm{SiO}_{2}$ & 53,92 & 52,92 & 49,63 & 54,83 \\
$\mathrm{Al}_{2} \mathrm{O}_{3}$ & 14,94 & 15,47 & 10,94 & 11,14 \\
$\mathrm{Fe}_{2} \mathrm{O}_{3}{ }^{*}$ & 5,15 & 4,96 & 12,98 & 1,01 \\
$\mathrm{CaO}$ & 19,37 & 21,18 & 12,46 & 29,42 \\
$\mathrm{MgO}$ & 3,28 & 2,98 & 10,53 & 2,73 \\
$\mathrm{Na}$ & 2,51 & 1,82 & 3,15 & 0,15 \\
$\mathrm{~K}_{2} \mathrm{O}$ & 0,84 & 0,67 & 0,40 & 0,70 \\
\hline
\end{tabular}

* Como hierro total: $\mathrm{FeO}+\mathrm{Fe}_{2} \mathrm{O}_{3}$ (As total iron: $\mathrm{FeO}+\mathrm{Fe}_{2} \mathrm{O}_{3}$ )

La micròmorfología de las fibras (Figura 8) indica una distribución de tamaños similar para todas: entre 5 y $20 \mu \mathrm{m}$ para Rockwool y Eurocoustic, 5-25 $\mu \mathrm{m}$ para Cultilene y 5-50 $\mu \mathrm{m}$ para Izolacja. E1 aspecto geométrico es muy uniforme en todas; Izolacja es la única que presenta defectos estructurales (Foto $\mathrm{C}$ ), posiblemente debidos a su composición.
The micromorphology (see Figure 8) shows a similar diameter distribution for the four samples: 5-20 um for Rockwool and Eurocoustic, 5-25um for Cultilene and 5-50 um for Izolacja. The geometric aspect is very uniform in all of them; Izolacja is the only one with structural defects (Photo C), probably as consequence of the composition. 

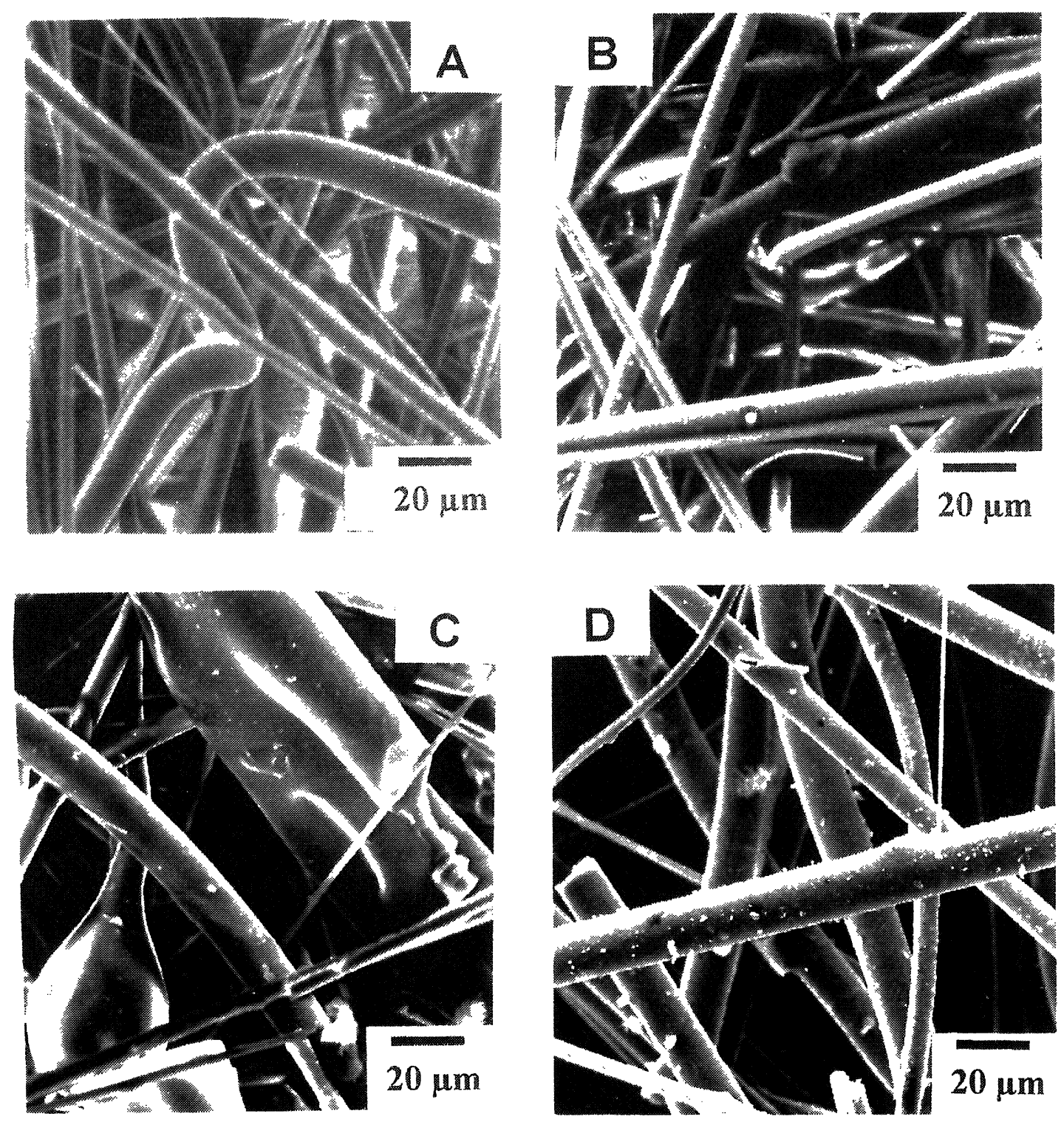

Fig. 8.- Micrografias MEB de las fibras comerciales: $(\Lambda)$ Rockwool, (B) Eurocoustic, (C) Izolacja y (d) Cultilene. Iig. 8.- SEM micrographs for the commercial fibers.

Todas las muestras son amorfas en DRX, no presentando reflexiones correspondientes a fases cristalinas (Figura 9). Su comportamiento térmico en atmósfera oxidante (aire), presenta efectos exotérmicos muy leves a $500^{\circ} \mathrm{C}$ para Rockwool y Eurocoustic, y más intensos para Izolacja (Figura 10) que, además, cuenta con otro pico exotérmico a $835^{\circ} \mathrm{C}$, asociado a la cristalización de augita (según se deduce de los resultados de DRX para esta muestra tratada a $800^{\circ} \mathrm{C}$ durante 4 horas). El pico en torno a $500^{\circ} \mathrm{C}$ se debe a la descomposición térmica de la resina polimérica usada en la manufactura de estos materiales.
All the samples are glassy by IDRX, without reflections due to crystalline phases (see Figure 9). The IDTA curves (in air) show smooth exothermic effects at $500^{\circ} \mathrm{C}$ ' for Rockwool and Eurocoustic, and more intense for Izolacja (see Figure 10). This sample has another effect at $835^{\circ} \mathrm{C}$ associated to the crystallization of augite (deduced from the DRX results for this sample treated at $800^{\circ}(4 h)$. The lower temperature effect is consequence of the degradation of the polymeric resin used in the manufacture of these materials. 


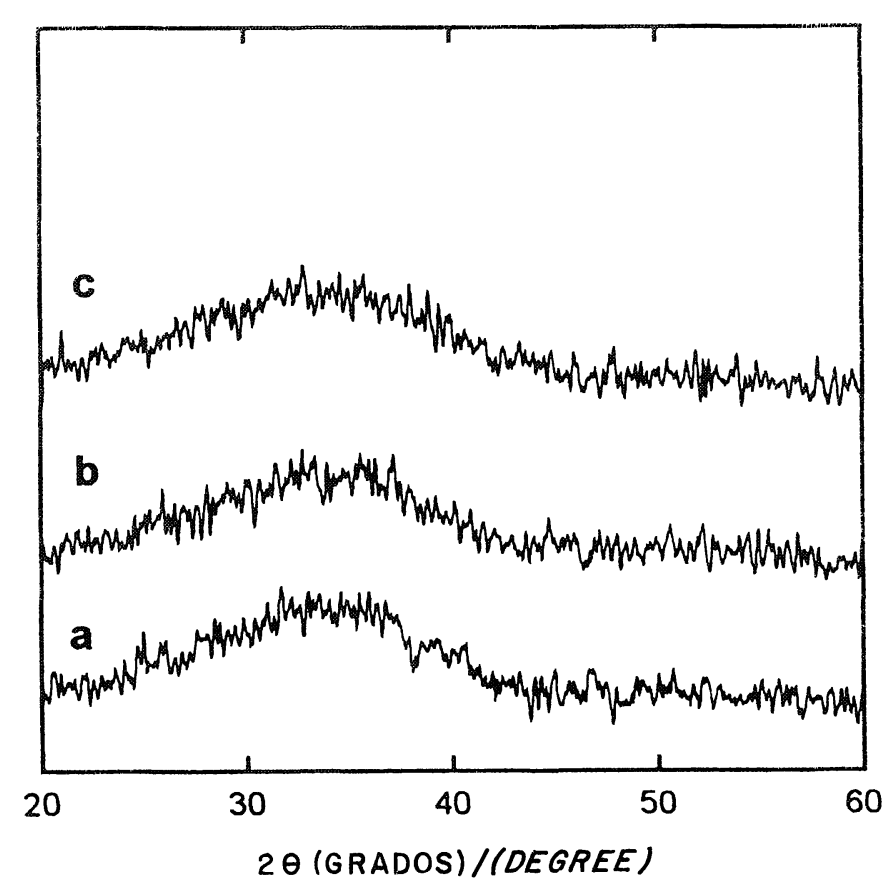

Fig. 9.- Difractogramas de rayos-X para las fibras comerciales: (a) Rockwool, (b) Eurocoustic y (c) Izolacja. $\operatorname{Rad} . \operatorname{CoK} \alpha$.

Fig. 9.- XRD patterns for the commercial fibers.

\section{CONCLUSIONES}

Se ha obtenido fibra en forma de lana mineral a partir de tres muestras de rocas de la Isla de Tenerife: dos basaltos y un traquibasalto. Para ello se ha empleado un proceso basado en el centrifugado del material fundido. De los datos de la viscosidad, calculados a partir de la composición química, se deduce que los dos basaltos, denominados B1 y B5, reúnen las mejores condiciones de cara a su transformación en fibra, pero no llegan a los valores considerados óptimos. En todo caso, es posible obtener fibra directamente a partir de ellos, si bien la adición de $\mathrm{CaCO}_{3}$ o de $\mathrm{CaMg}\left(\mathrm{CO}_{3}\right)_{2}$ aumenta la cantidad producida y mejora notablemente la calidad de las fibras, reduciendo el diámetro. En el caso de la otra muestra, el traquibasalto B2, es necesaria la adición de esas sustancias con el fin de obtener fibra, y en mayor proporción que para las dos otras muestras, debido a su mayor contenido en sílice y alúmina.

La distribución de diámetros es bastante amplia para las fibras obtenidas experimentalmente, y disminuye por efecto de los aditivos en la composición original. El estudio por TEM de las muestras denominadas 1 y 5 revela la presencia de cristalizaciones y una elevada separación de fases, que junto a los datos de DRX y ATD nos hace prever una alta tendencia a la desvitrificación para este tipo de fibras. Teniendo en cuenta que ello implica la pérdida de resistencia

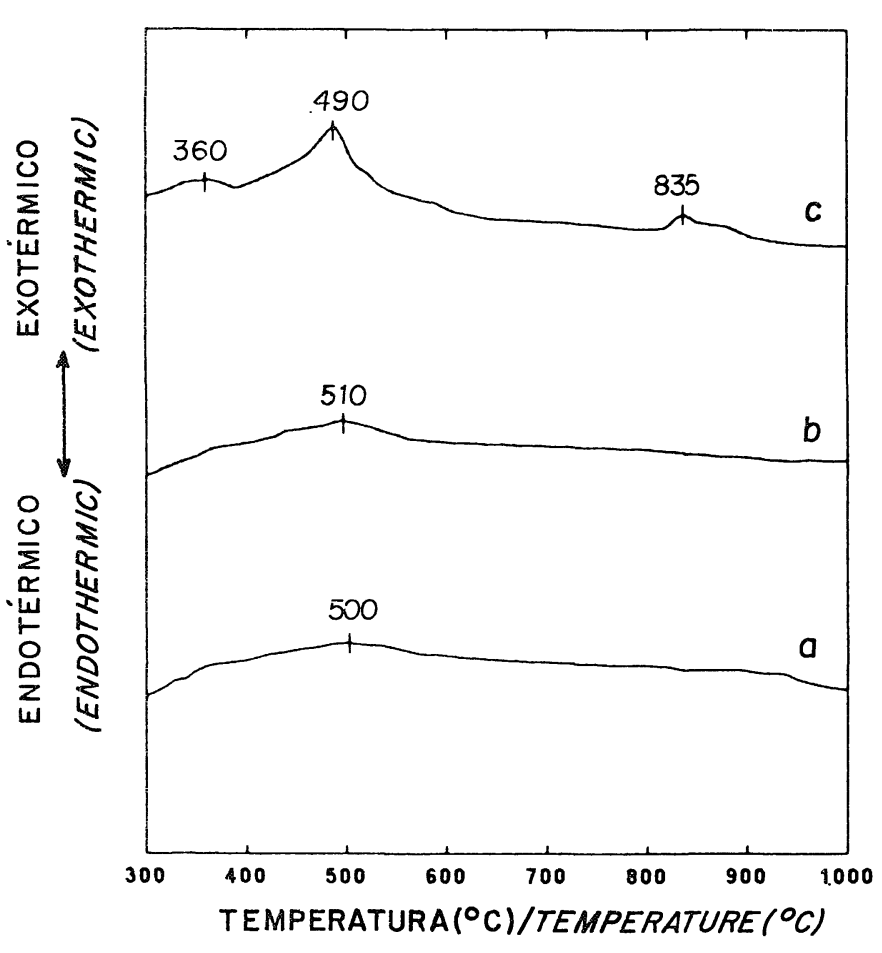

Fig. 10.- Curvas ATD para las fibras comerciales: (a) Rockwool, (b) Eurocoustic y (c) Izolacja.

Hig. 10.- D'TA curves for the commercial fibers.

\section{CONCLUSIONS}

Fiber moulded as mineral wool was obtained from three samples of rocks from the Tenerife Island (Spain): two basalts and a trachybasalt. The process used consists in the spinning of the molten material. The viscosity data, calculated from the chemical composition, shows that the two basalts, named Bl and $B 5$, possess the best conditions to be transformed in fiber, but do not reach the values assumed as optimum. Nevertheless, it is possible to get fiber directly from them, but the produced quantity is increased by adding $\mathrm{CaCO}$ or $\mathrm{CaMg}\left(\mathrm{CO}_{3}\right)_{2}$, and the quality is notablely improved, reducing the diameter. For the other rock sample, the trachybasalt B2, the addition of those substances is needed to obtain fibers, and in higher proportions than for the other two samples, because the higher content in silica and alumina.

The diameter distribution of the experimental fiber is very broad, but decreases as consequence of the additives. The TEM study of the samples named 1 and 5 shows the presence of crystallizations among a large phase separation. This, together with the DRX and DTA results, reveals a high tendency to crystallize for these fibers. As the microcracks between the crystals and the residual glassy phase involve a loss in the mechanical properties, the maximum temperature of 
mecánica, por la aparición de microgrietas entre los cristales y la fase vítrea residual, la temperatura máxima de trabajo para estas fibras se sitúa en torno a $500{ }^{\circ} \mathrm{C}$, aunque sería necesario un estudio más detallado al efecto para establecer con mayor exactitud este límite.

De la comparación con los datos obtenidos para las fibras de tipo comercial, vemos que el aspecto estructural de las muestras 1 y 5 se asemeja mucho al de Izolacja, en tanto que el resto se aproxima a lo observado para las muestras Rockwool y Eurocoustic. La composición de las fibras obtenidas a partir de los basaltos B1 y B5 es muy semejante a la de Izolacja, destacando el alto contenido en hierro, un poco más bajo en la serie de B2, pero no lo suficiente para estar al mismo nivel de Rockwool y Eurocoustic. No parece que la composición de las fibras experimentales sea adecuada para emplearlas como sustrato de suelo artificial, si las comparamos con Cultilene. Respecto al análisis térmico, las fibras experimentales presentan un efecto exotérmico, en torno a $840{ }^{\circ} \mathrm{C}$, debido a la cristalización del vidrio, comportamiento sólo detectado en la muestra Izolacja. En definitiva, las características morfológicas y microestructurales de las fibras obtenidas por adición de $\mathrm{CaCO}_{3}$ y $\mathrm{CaMg}\left(\mathrm{CO}_{3}\right)_{2}$ son comparables a las de la lana mineral de tipo comercial, más concretamente a las muestras Rockwool y Eurocoustic, lo que hace prever unas buenas cualidades como material aislante térmico-acústico, si bien con mayor tendencia a la desvitrificación. use for these fibers is around $500^{\circ} \mathrm{C}$. A study in depth in this sense is necessary to establish with more accuracy this limit.

Comparing with the commercial fibers data, the structural aspect of the samples 1 and 5 is very similar to Izolacja, and the others are closed to Rockwool and Eurocoustic. The composition of the fibers derived from the basalts $B 1$ and $B 5$ is not very different of the Izolacja sample, except for a higher content in iron. For the 32 group the iron content is lower, but not enough to be at the same level than Rockwool and Eurocoutic. Do not seem that the experimental fibers composition are suitable for using like artificial soil, comparing with Cultilene. In regard to the thermal analysis, all the experimental fibers have an exothermic effect around $840^{\circ} \mathrm{C}$, associated to the crystallization of the glass. This behavior was only detected in the sample Izolacja. Anyway, the morphological and microstructural characteristics of the fibers obtained by the addition of $\mathrm{CaCO}_{3}$ or $\mathrm{CaMg}\left(\mathrm{CO}_{3}\right)_{2}$ are comparable to the ones on the commercial mineral wool, specifically Rockwool and Eurocoustic. This gives good prospects to these fibers as thermo-acoustic insulation, although with a higher tendency to crystallize.

\section{BIBLIOGRAFÍA}

(1) ÖHBERG, I.: "Technological development of the mineral wool industry in Europe". Ann. Occup. Hyg., 31, 4B, (1987), pp. 529545.

(2) WOJNAROVITS, I.: "Heat-induced structural and mechanical changes of basalt wool". Glastech. Ber. 61, 6, (1988), pp. 157-160.

(3) WOJNAROVITS, I. and FODOR, M.: "Modelling of chemical and morphological changes of silicates fibres used in a portland cement matrix". Glastech. Ber., 64, 6, (1991), pp. 155-160.

(4) RAMACHANDRAN, B. E., VELPARI, V. and BALASUBRAMANIAN, N.: "Chemical durability studies on basalt fibres". J. of Mat. Sci., 16, (1981), pp. 3393-3397.

(5) YILMAZ, V. T. and GLASSER, F. P.: "Reaction of alkali-resistant glass fibres with cement. Part 1. Review, assessment and microscopy”. Glass Tech., 32, 3, (1991), pp. 91-98.

(6) SUBRAMANIAN, R. V., WANG, T. J. and AUSTIN, H. F.: "Reinforcement of polymers by basalt fibers". Sampe Q., 8, 4, (1977), pp. 1-10.

(7) PARK, J.M. and SUBRAMANIAN, R.V.: J. Adhesion Sci. Technol., 5, 6, (1991), pp 459-477.

(8) PARK, J.M. and SUBRAMANIAN, R.V.: "Effects of silane coupling agents on internal reinforcement of wood by E-glass and basalt fibers". J. Adhesion Sci. Technol., 8, 12, (1994), pp. 1473-1483. 
(9) VICENTE-MINGARRO, I., CALLEJAS, P. y RINCÓN, J. Ma...: "Caracterización de basaltos canarios como materia prima para a fabricación de fibra de vidrio y materiales vitrocerámicos" en Ciencia y Tecnología de los Materiales Cerámicos y Vitreos, editor Rincón, J. Ma., SECV- Faenza Editrice Iberica, (1990) Castellón, pp 75- 78.

(10) CÁCERES, J., GARCÍA HDEZ., J., CALLEJAS, P. and RINCÓN J.M".: "Microstructural and analytical characterization of some commercial and experimental mineral glass fibers". Glass Technology, 34, 4, (1993), pp. 159-162.

(11) LAKATOS, T., JOHANSSON, L. G. and SIMMINGSKÖLD, B.: "Viscosity and liquidus temperature relations in the mineral wool part of the system $\mathrm{SiO}_{2}-\mathrm{Al}_{2} \mathrm{O}_{3}-\mathrm{CaO}-\mathrm{MgO}-\mathrm{Alkalis}-\mathrm{FeO}-\mathrm{Fe}_{2} \mathrm{O}_{3}$. Glasteknisk Tidskrift, 36, 4, (1981), pp. 51-55.

(12) MOHR, J.G. and ROWE, W.P.: "Fiber glass", VNR, New York (1978).

(13) BEA BARREDO, F., and POLO DIEZ, L.: "Optimization of silicate rocks decomposition for determination of major elements by AAS". Talanta, 3, (1976), pp. 859-61.

(14) ASTM D1577-90: "Standard test method for linear density of textiles fibers".

(15) QUON, D. H. H., and WANG, S. S.: "Viscosity-temperature relationship of materials used for the experimental production of mineral wool". J. of the Canadian Ceramic Soc., 50, (1981), pp. 17-22.

(16) VOGEL, W.: "Chemistry of Glass". Am. Cer. Soc., Columbus (Ohio), (1985).

(17) ANDREEVSKAYA, G.D. and PLISKO, T.A.: "Some physical properties of continuous basalt fibers". Steklo i Keramica, 20, 8, (1963), pp. 15-18.

\section{publicación del IETCC/CSIC}

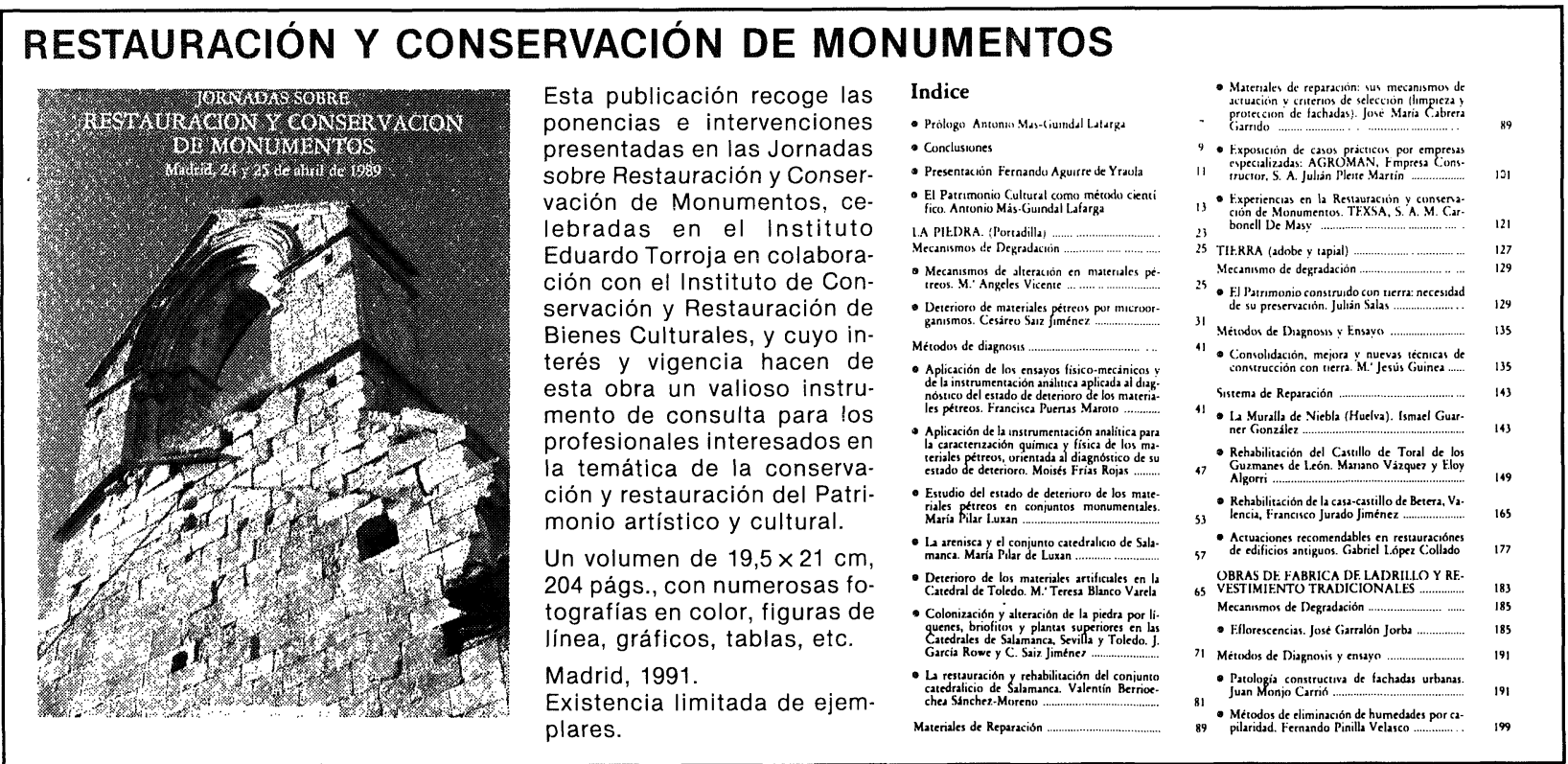

